Extensional Article

\title{
Biological control method of postharvest fungal diseases of apple
}

\author{
PARMIDA ALEAHMAD, LEILA EBRAHIMI ${ }^{\bowtie}$ \\ College of Aburaihan, University of Tehran, Tehran, Iran
}

Received: 12.11.2020

Accepted: 02.22.2021

Aleahmad P, Ebrahimi L (2020) Biological control method of postharvest fungal diseases of apple. Plant Pathology Science 9(2):95-107. DOI: 10.2982/PPS.9.2.95.

\begin{abstract}
Apple postharvest diseases are usually caused by a wide range of pathogenic fungi. Postharvest rot of this crop is one of the most important economic diseases and also one of the main factors in reducing the lifespan of this crop. In contrast, our current knowledge of the occurrence and latent contamination during storage and its epidemiology is limited. The pathogenic fungi Botrytis cinerea and Penicillium expansum causing gray mold and blue mold, respectively, are the most common pathogens in the cultivation areas, which are usually inhibited by the use of synthetic fungicides. However, due to the growing concern over the use of synthetic fungicides, alternative control measures such as using physical treatments, natural compounds, and biocontrol agents are highly desired. Although no method has been approved as a definitive method of postharvest diseases management, the effectiveness of yeasts such as Candida saitoana, bacteria such as Rahnella aquatilis, and fungal species such as Trichoderma harzianum has been suggested.
\end{abstract}

Key words: Botrytis, Candida, Penicillium, Trichoderma

$\bowtie$ Corresponding author: Le_ebrahimi@ut.ac.ir 


$$
\begin{aligned}
& \text { مقاله ترويجى } \\
& \text { روش مبارزه زيستى با بيمارىهاى قارجى هس از برداشت سيب } \\
& \text { يارميدا آل احمد، ليلا ابراهيمى } \\
& \text { يرديس ابوريحان، دانشگاه تهران }
\end{aligned}
$$

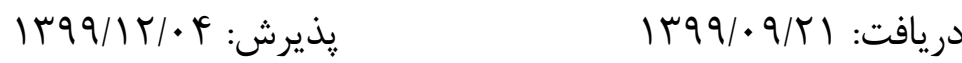

آلاحمد ״ֶ، ابراهيمى ل (99 (1) روش مبارزه زيستى با بيمارىهاى قـارجى يـس از برداشـت سـيب.

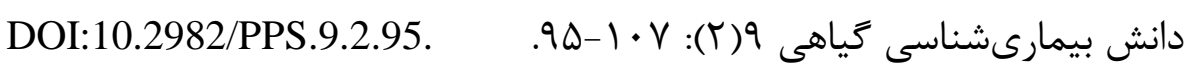

بيمارىهاى يس از برداشت سيب، معمولاً توسط طيف وسيعى از قارجها به وجود مى آيند. يوسيدگى يس از برداشت اين ميوه، مهمترين دليل كاهش طول عمر و ارزش اقتصادى آن به شمار مى آيند.

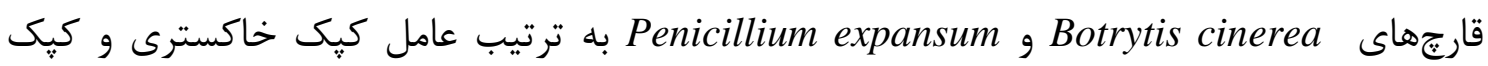
آبى، شايعترين عاملهاى يوسيدگى بعد از برداشت ميوه سيب شناخته شدهاند. استفاده از سمهاى شيميايى براى مبارزه با اين قارجها مىتواند اثرهاى سوء بر سلامت مصرفكنند داشته و سبب بروز مقاومت در قار جها و از بين رفتن جانداران مفيد شود. بنابراين مبارزه زيستى با اين

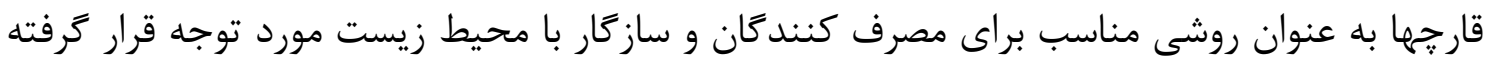
است. كارآيى قارجهاى Candida saitoana و Trichoderma harzianum و و باكترى Rahnella aquatilis وازگًان كليدى: Botrytis, Candida, Penicillium, Trichoderma

\section{مقدمه}

سيب از مهمترين ميوههاى دانهدار است كه در سراسر دنيا به طور كسترده كشت مىشود و به دليل وجود مقدار بالاى مواد مغذى مورد حمله انواع عوامل بيمارگر در مراحل مختلف، از كاشت تا مصرف قرار مى گيرد. بيمارىهاى يس از برداشت سيب هر ساله در سراسر دنيا باعث ضررهاى شديد اقتصادى در هنخام نتحهدارى در انبار مىشود كه توسط طيف وسيعى از عوامل بيمارىزاى قارجى و برخى از باكترىها و شباقارجها ايجاد مىشود (Wenneker and Thomma 2020). با وجود ييشرفتهاى صورت گرفته در فناورى نكمهارى ميوههاى تازه بعد از برداشت، ميزان تلفات ناشى از عوامل ميكروبى در ميوههاى سيب از ينج تا · r درصد بسته به گَونه و تكنولوزى مورد استفاده در بستهبندى و شرايط

هائول مكاتبه:Le_ebrahimi@ut.ac.ir 
انباردارى (دما، رطوبت و ...) متفاوت است و در مورد ارقام حساس تا • له درصد هم برآورد شده است (Janisiewicz and Korsten 2002). در سراسر دنيا قارجهاى مختلفى از جمله: Neofabraea alba، Phytophthora ،Cadophora malorum ،Colletotrichum acutatum „Neonectria ditissima Sphaeropsis ‘Phacidium lacerum ‘Fusarium spp. Alternaria spp. spp. Monilinia ‘Penicillium expansum ‘Phacidiopycnis washingtonensis.pyriputrescens Botrytis cinerea fructigena

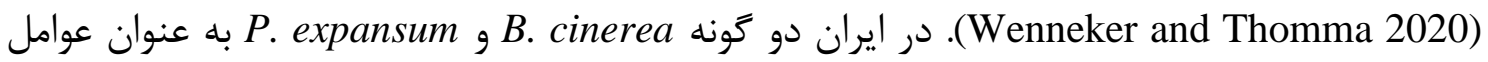
بيماريزاى يس از برداشت سيب با خسارت اقتصادى گزارش شدهاند. زخمهاى ناشى از حمله يرندكان، حشرات و صدمات فيزيكى ايجاد شده در قبل و حين برداشت، محل ورود اين عوامل بيمارىزا هستند كه در نهايت باعث يوسيدگى قبل و گِ إز برداشت مىشوند و حتى در مناطقى با تكنولوزىهاى بالاى انباردارى هم خسارتزا هستند(Snowdon 1990). كاربرد بعضى قارجكشهاى شيميايى به طور جشمى جيرى باعث كاهش خسارت آنها مىشود (Wenneker and Thomma 2020)، اما امروزه به دليل خطرهاى ناشى از سميت قارجكشهاى شيميايى بر سلامت مصرفكنندگان به دليل دوره طولانى تجزيه و سرطانزا بودن (Janisiewicz and Korsten 2002)، پايدارى در محيطزيست و تجمع در بافت ميوه و بدن انسان، بيدايش جدايههاى قارجى با مقاومت بالا، از بين رفتن ريزجانداران مفيد، بروز آفتها و بيمارىهاى ثانويه، استفاده از سمهاى شيميايى محدود شده است و راهكارهاى جايكزين در حال مطالعه و توسعه هستند (Talibi et al. 2014). از بين روشهاى مختلف جايكزين مبارزه شيميايى، كاربرد ريزجانداران متعارض براى مديريت بيمارى، محبوبيت زيادى در بين يزوهشكران يافته است، كه در اين مقاله يافتههاى جديد كاربردى روشهاى مبارزه زيستى با يوسيدگى هاى پر از برداشت سيب شرح داده شدهاند.

\section{بيمارىهاى مهم قارجى هـ از برداشت سيب} 1- 1

قارجPenicillium expansum Link از شايعترين و مخربترين بيمارگرهاى يس از برداشت ميوههاى دانهدار است كه باعث ايجاد يوسيدگى هاى شديد روى ميوهها در انبار و كاهش ماندگًارى محصول مى شود (Gholamnejad et al. 2009) همجنين اين قارج توكسين خطرناكى به نام پاتولين توليد مى كند كه سلامت انسان را تحت تأثير قرار مىدهد (El-Ghaouth et al. 2004 ). اين قارج از راه زخمم وارد بافت مىشود ولى مىتواند از ميوه آلوده به يوست آسيب نديده ميوههاى مجاور نيز رخنه كند. نشانهها به صورت لكههاى نرم، خيس، كمى تغيير رنى يافته، به اندازههاى مختلف و در هر جاى ميوه 
ظاهر مىشوند كه در آغاز سطحىاند ولى به سرعت عميق مىشوند. در دماى اتاق بيشتر يا تمام ميوهها در طى جند روز فاسد مىشوند. در ابتدا كيك سفيدى بر سطح بوست، نزديك مركز لكه به وجود مى آيد و شروع به توليد هات مى كند. اين ناحيه به رنگ آبى، سبز مايل به آبى يا سبز زيتونى درمى آيد كه با نوارى از ميسليوم سفيد احاطه شده است. در هواى گرم و مرطوب، قارج روى لكهها توسعه مىيابد ولى در هواى خنك و خشك حتى اگر تمام ميوه هم فاسد شود روى سطح آن كيك

تشكيل نمىشود (Agrios 2005 ).

r-كيك خاكسترى كيك خاكسترى ناشى از قارج .Botrytis cinerea Pers يكى از مخربترين بيمارىهايى است كه سبب يوسيدگى جزئى در فصل زراعى و يوسيدگى قابل توجه در انبار مىشود. اين قارج دومين بيماركر مخرب بعد از كيك آبى روى سيب است (Rosenberger 1990). فساد ناشى از اين كيك در كلكًاه يا دمكاه ميوهها يا از محل هر نوع زخمى آغاز مىشود كه ابتدا به صورت ناحيه لهيده مشخصى كه اندكى بعد متمايل به قهوهاى مىشود يديدار مىشود، عميقاً در بافت نفوذ مى كند و به سرعت توسعه پِيدا مى كند. در بيشتر ميزبآنها و در شرايط رطوبت زياد، لايهاى از كيك خاكسترى يا خاكسترى مايل به قهوهاى بر سطح نواحى فاسد ايجاد مىشود. شرايط مطلوب براى اين بيمارى هواى خنك و مرطوب است و حتى در دماى صفر درجه سلسيوس هم به كندى رشدش را ادامه مىدهد

.(Agrios 2005)

\section{روشهاى مبارزه زيستى با بيمارىهاى يس از برداشت سيب}

مبارزه زيستى (Biological control) به معنى كاربرد ريزجانداران متعارض با بيمارگرهاى گياهى است. جانداران مورد استفاده در مبارزه بيمارىهاى پيس از برداشت، يا به صورت ايىفيت در سطح ميوهها وجود دارند و يا به صورت انتخابى، در قبل يا بعد از آلودگى در محل قرار داده و استقرار مىيابند. تأثير وجود اين ريزجانداران كه به طور طبيعى روى ميوهها وجود دارند هنگامى مشخص مى مى شود كه ميوههايى كه شسته شدهاند نسبت به ميوههاى شسته نشده نشانه بيشترى نشان مىدهند و سريعتر دجار آلودگى مىشوند (Droby et al. 1998 ). عمليات مبارزه زيستى از طريق سازوكارهاى مختلفى موجب تضعيف يا از بين رفتن بيمارگرها مىشود كه عبارتند از: يارازيته كردن مستقيم بيماركرها، توليد آنتىبيوتيك (يادزيست) عليه بيمارگر، ايجاد رقابت در فضا و مواد غذايى، توليد آنزيمهايى كه سلولهاى بيمارگر را مورد حمله قرار مىدهد، القاى مقاومت در گياه ميزبان، تحريك زياه به توليد مواد مترشحه دفاعى و احتمالاً به كاركيرى روشهاى ديخر كه به خوبى براى ما شناخته 
شده نيست (Agrios 2005). برخى از تلفيق קند روش و بعضى فقط با بكارگيرى يكى از روشها عامل بيمارگر را محدود و سركوب مى كنند (Parveen et al. 2016 ). ا. پارازيته كردن مستقيم بيمارگرها يا فراانكلى (Hyperparasitism): در اين مكانيزم جاندار متعارض، بيماركر را شناسايى مى كند و يس از تماس نزديك با ترشح آنزيمهاى تجزيهكننده و يا رشد فعال درون بيمارگر باعث كاهش توانايى بيمارگر در ايجاد بيمارى و تضعيف آن مىشود. در اين حالت بيماركر و يا اندامهاى تكثيرى آن را از بين مىبرد (Spadaro 2002). به عنوان مثال، سازوكار

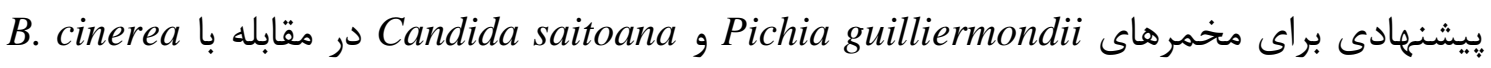
توانايى اتصال به ريسههاى بيمارگر و ترشح آنزيمهاى تجزيه كننده ديواره سلولى آن است .( El-Ghaouth et al. 1998) ז. توليد مواد هادزيست (Antibiosis): از مهمترين روشهاى مبارزه زيستى است. اين فعاليت در باكترىها بيشتر از مخمرها و قارجهاى رشتهاى ديده مىشود (Ramezani and Mahdian 2016 ). اين سازوكار به دو صورت ديده مىشود: () اثر سمى مستقيم با ترشح آنتىبيوتيكها، r) اثر سمى غيرمستقيم با توليد مواد فرار مانند اتيلن كه در نتيجه فعاليتهاى متابوليكى ريزجانداران متعارض در محيط آزاد مىشوند و روى بيماركرها اثر مى گذارند. امروزه گزارشهاى زيادى از غالب سودوموناسها

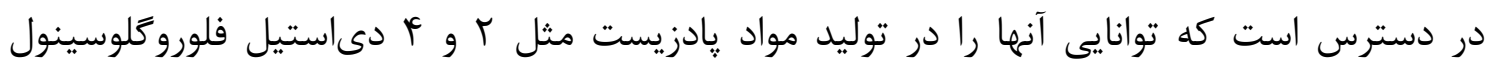
اثبات كردهاند (Iavicoli et al. 2003). همجنين توليد يِيرولنيترين، يك تركيب ضدقارجى در Pseudomonas cepacia شده است (Janisiewicz and Roitman 1988) نحوه مقابله Bacillus subtilis با B. cinerea توليد برخى سيكلولييوِيتيدها مثل fengecins حدس زده مىشود (Ongena et al. 2005 ). قارج I, P. expansum و B. cinerea نيز توانايى توليد مواد پادزيست عليه Aureobasidium pullulans دارد ( Castoria et al. 2001). r. رقابت (Competition): منابع غذايى موجود در سطح ميوهها براى تمام ريزجانداران كافى نبوده و در نتيجه باعث ايجاد رقابت بين بيمارگرها و متعارضها براى استقرار و تأمين مواد غذايى مىشود ( Liu et al. 2009). ريزجانداران غيربيمارگر، به خصوص مخمرها با اشغال سريع محل زخمها و سطح ميوهها از ورود و تماس بيماركرها جلوگيرى مىكنند. نقش ييشنهادى براى مخمر Cryptococcus laurentii اشغال محلهاى آلودگى و رقابت بر سر مكان استقرار در مقابله با قارج B. cinerea توسط مخمر Candida oleophila 
F. مقاومت القايى: القاى مقاومت در كياهان ميزبان توسط عوامل متعدى ايجاد مىشود. از جمله حضور ريزجانداران متعارض، عوامل فيزيكى ماند كرما و نور UV-C، تركيبهاى شيميايى مانند اسيد ساليسيليك (Palou et al. 2016) و بسيارى از مواد ديكر مىباشد. به عنوان مثال، تحريك سيستم دفاعى كياه ميزبان در مقابل B. cinerea توسط Candida saitoana صورت مى كيرد (El-Ghaoutht et al. 1998). مخمر باعث القا واكنش دفاعى در ميزبان از طريق افزايش بيان P. expansum زنهاى دفاعى و در نتيجه آنزيمهايى مانند بروكسيداز و همينين تركيبهاى فنلى عليه مىشود (Ebrahimi et al. 2013b).

جانداران موثر در مبارزه با يوسيدكى يس از برداشت سيب

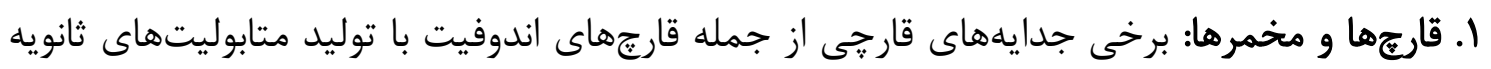

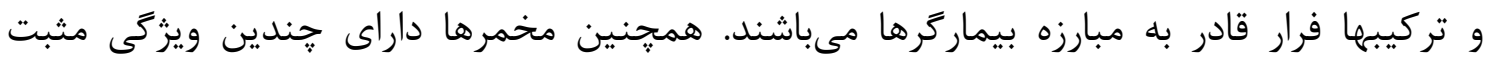

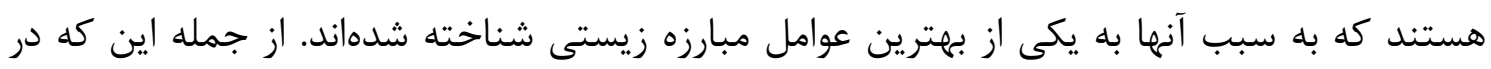

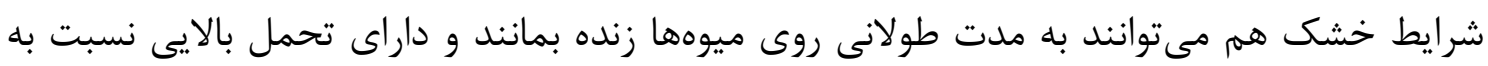

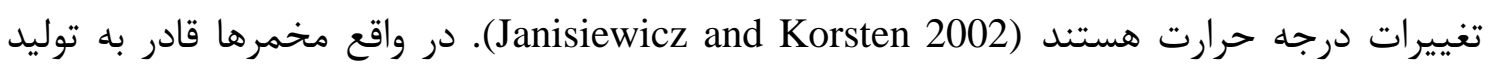

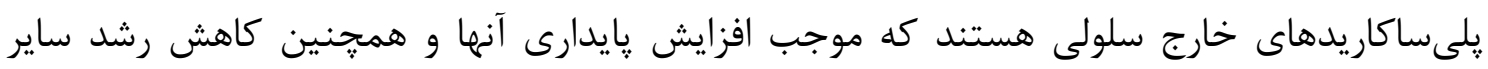
بيماركرها مىشود. علاوه بر اين مخمرها مىتوانند به سرعت از مواد غذايى محيط استفاده كرده و

سريع تكثير شوند (Sharma et al. 2009).

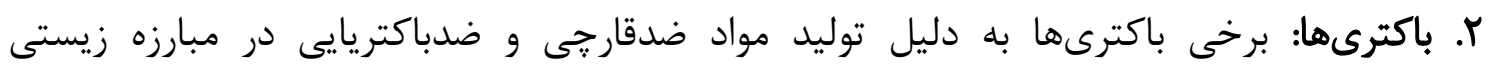

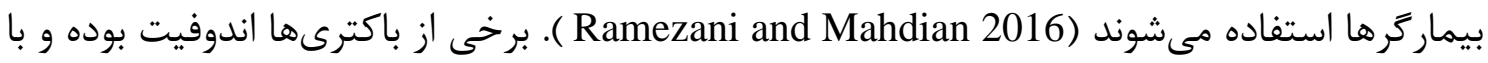

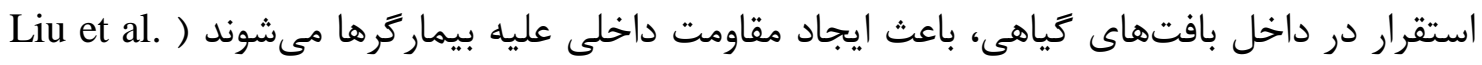

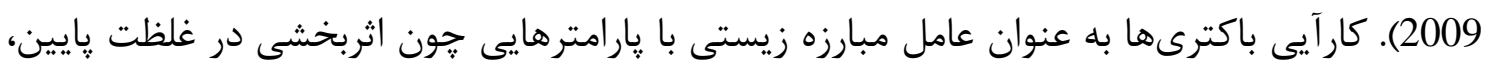

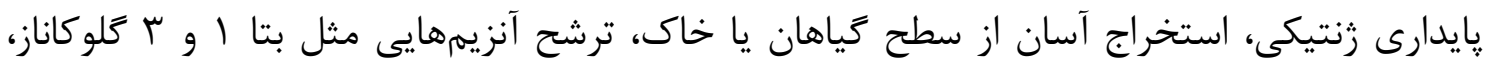
كيتيناز و يروتئز كه به ترتيب باعث تجزيه كَلوكان، كيتين و يروتئين موجود در ديواره سلولى قارجها

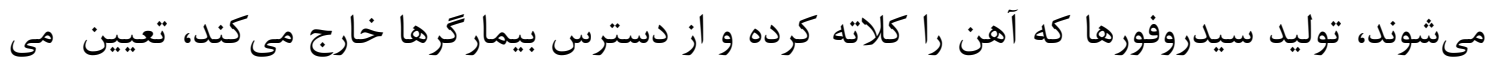
شوند (Carmona-Hernandez et al. 2019). تعدادى از قارجها و باكترىهاى موثر در مديريت بيماريهاى بعد از برداشت سيب در جدول النام برده شدهاند. 


$$
\text { جدول ا. برخى جانداران مورد استفاده در مبارزه بيمارگرهاى يس از برداشت سيب. }
$$

Table 1. Some biocontrol agents to manage apple postharvest pathogens.

\begin{tabular}{|c|c|c|}
\hline Pathogen & Antagonistic agents & References \\
\hline \multirow[t]{6}{*}{ Penicillium expansum } & Pichia membranifaciens & Chan et al. 2007 \\
\hline & Torulaspora delbrueckii & Ebrahimi et al. 2012a, b \\
\hline & Trichoderma reesei & González-Estrada et al. 2018 \\
\hline & Trichoderma atroviride & \\
\hline & Bacillus amyloliquefaciens & Carmona-Hernandez et al. 2019 \\
\hline & Pseudomonas fluorescens & \\
\hline \multirow[t]{17}{*}{ Botrytis cinerea } & Candida oleophila & Mercier and Wilson 1994 \\
\hline & Sporobolomyces roseus & \\
\hline & Filobasidium floriforme & Filonow et al. 1996 \\
\hline & Rhodosporidium toruloides & \\
\hline & Cryptococcus humicola & \\
\hline & Cryptococcus laurentii & Yu et al. 2008 \\
\hline & Metschnikowia fructicola & Pelliccia et al. 2011 \\
\hline & Debaryomyces hansenii & \\
\hline & Rhodotorula mucilaginosa & Li et al. 2011 \\
\hline & Hanseniaspora opuntiae & Ruiz-Moyano et al. 2016 \\
\hline & Pichia guilliermondii & Li et al. 2016 \\
\hline & Candida sake & Arrarte et al. 2017 \\
\hline & Citeromyces matritensis & Kheireddine et al. 2018 \\
\hline & Cryptococcus flavescens & \\
\hline & Aureobasidium pullulans & Mercier and Wilson 1994 \\
\hline & Clonostachys rosea & Reeh 2012 \\
\hline & Erwinia sp. & Kampp 1990 \\
\hline \multirow[t]{17}{*}{$\begin{array}{l}\text { P. expansum and } \\
\text { B. cinerea }\end{array}$} & Candida guilliermondii & McLaughlin et al. 1990 \\
\hline & Kloeckera apiculata & McLaughlin et al.1992 \\
\hline & Candida saitoana & El-Ghaouth et al. 1998 \\
\hline & Cryptococcus albidus & Fan and Tian 2001 \\
\hline & Metschnikowia pulcherrima & $\begin{array}{l}\text { Spadaro et al. 2002, Ebrahimi et al. } \\
\text { 2013a, b, Ruiz-Moyano et al. } 2016\end{array}$ \\
\hline & Rhodotorula glutinis & Zhang et al. 2009 \\
\hline & Saccharomyces cerevisiae & Gholamnejad et al. 2009 \\
\hline & Candida membranifaciens & Gholamnejad et al. 2010 \\
\hline & Leucosporidium scottii & Vero et al. 2013 \\
\hline & Candida membranifaciens & Aminian et al. 2019a, b \\
\hline & Pichia guilliermondii & \\
\hline & Saccharomyces cerevisiae & \\
\hline & Trichoderma harzianum & Batta 2003, 2004 \\
\hline & Burkholderia cepacia & Janisiewicz and Roitman 1988 \\
\hline & Pseudomonas syringae & Zhou et al. 2001 \\
\hline & Rahnella aquatilis & Calvo et al. 2007 \\
\hline & Bacillus subtilis & Wang et al. 2010 \\
\hline
\end{tabular}




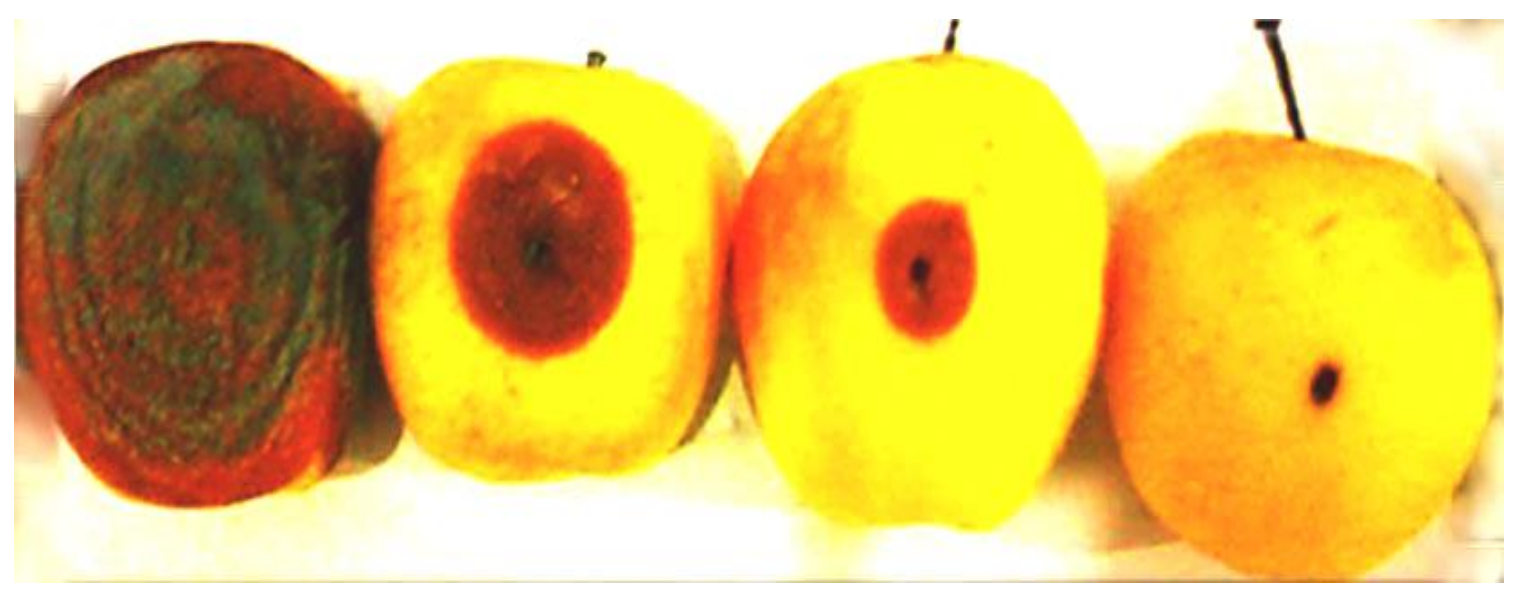

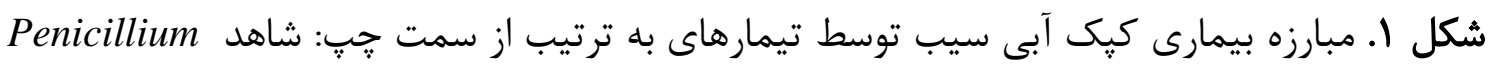

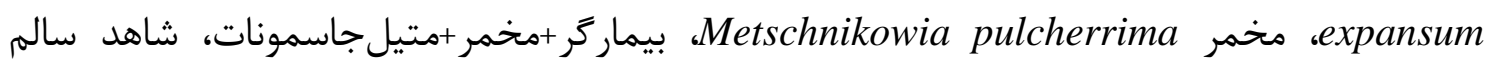

Figure 1. Biocontrol of apple blue mold disease using, respectively from left: Penicillium expansum, Metschnikowia pulcherrima, pathogen+yeast+methyl jasmonate, untreated control.

\section{كاربرد ساير تركيبهاى زيستى در مبارزه با بيمارىهاى ڤس از برداشت سيب}

بعضى تركيبها خاصيت ميكروبكشى دارند و مىتوانند به تنهايى و يا در تركيب با ساير عوامل مبارزه

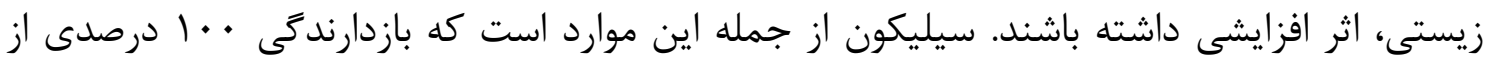
رش M. pulcherrima در شرايط آزمايشكاهى داشته و در تركيب با دو مخمر P. expansum T. delbrueckii

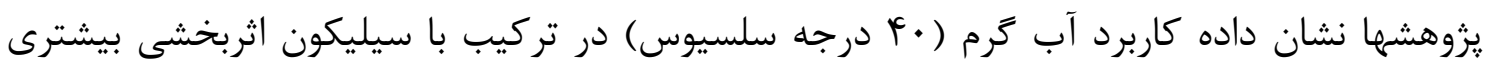
نسبت به سيليكون دارد (Etebarian et al. 2013 ). متيلجاسمونات، يكى ديكر از اين تركيبها است، كه به تنهايى باعث كاهش كيك آبى و در تركيب با M. pulcherrima و بهبود عملكرد آنها شده است (شكل () (Ebrahimi et al. 2012b, 2013b). كاز هاى CO CO و ازن مانع جوانهزنى هاكى قارجهاى B. cinerea P. expansum شده و خاصيت قارجكشى دارد. اين كازها در تركيب با مخمرهاى C. membranifaciens و Aاعث افزايش كار آيى اين مخمرها شداند (Aminian et al. 2019a, builliermondii

\section{نتيجه كيرى}

بيمارىهاى بس از برداشت سيب توسط طيف وسيعى از قارجها ايجاد مىشوند كه كاهى باعث از بين

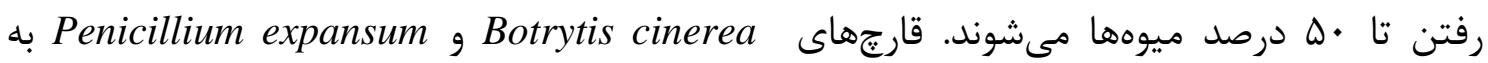
ترتيب عامل كيك خاكسترى و كيى آبى، شايعترين عاملهاى يوسيدگى بعد از برداشت ميوه سيب 
در ايران شناخته شدهاند. استفاده از سمهاى شيميايى براى مبارزه با اين قارجها مىتواند اثرهاى سوء بر سلامت مصرفكنندكان و محيطزيست داشته و سبب بروز مقاومت در قارجها و از بين رفتن

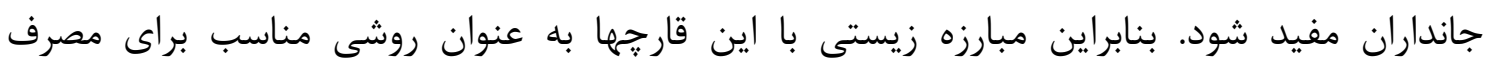
كنندكان و سازگار با محيط زيست مورد توجه قرار كرفته است. كارآيى قارجهاى Trichoderma harzianum و باكترى Candida saitoana با اين بيمارىها به اثبات رسيده است. براى نتيجهگيرى بهتر، بايد اين ريزجانداران متعارض را با روشهاى ديخر از جمله استفاده از روشهاى فيزيكى مثل استفاده از اشعه و كازها، تركيبهاى طبيعى و غيره تلفيق كرد، تا ضمن كاهش مصرف سمهاى شيمايى و خطرهاى ناشى از مصرف آنها براى محيطزيست و مصرفكنندگان، از ييشرفت و وقوع اين بيمارىها جلو گيرى كرد.

\section{References}

1. Agrios GN (2005) Plant pathology. Elsevier Academic Press, Burlington, MA, USA, $344 p$.

2. Aminian H, Sadeghi R, Sheikh M, Ebrahimi L (2019a) Control of apple blue and gray molds using antagonistic yeasts and CO2. First Iranian Plant Pathology Congress, 31 August- 1 September, University of Tehran, Karaj, Iran. (In Persian with English Abstract).

3. Aminian H, Sadeghi R, Sheikh M, Ebrahimi L (2019b) Investigation of the antagonistic yeasts and ozone effect in controlling apple blue and gray molds. First Iranian Plant Pathology Congress, 31 August-1 September, University of Tehran, Karaj, Iran. (In Persian with English Abstract).

4. Arrarte E, Garmendia G, Rossini C, Wisniewski M, Vero S (2017) Volatile organic compounds produced by Antarctic strains of Candida sake play a role in the control of postharvest pathogens of apples. Biological Control 109:14-20.

5. Batta YA (2003) Postharvest biological control of apple gray mold by Trichoderma harzianum Rifai formulated in an invert emulsion. Crop Protection 23:19-26.

6. Batta YA (2004) Effect of treatment with Trichoderma harzianum Rifai formulated in invert emulsion on postharvest decay of apple blue mold. International Journal of Food Microbiology 96:281-288.

7. Calvo J, Calvente V, de Orellano ME, Benuzzi D, de Tosetti MIS (2007) Biological control of postharvest spoilage caused by Penicillium expansum and Botrytis cinerea in apple by using the bacterium Rahnella aquatilis. International Journal of Food Microbiology 113:251-257.

8. Carmona-Hernandez S, Reyes-Pérez JJ, Chiquito-Contreras RG, Rincon-Enriquez G, Cerdan-Cabrera CR, Hernandez-Montiel LG (2019) Biocontrol of postharvest fruit fungal diseases by bacterial antagonists: A review. Agronomy 9:121. 
9. Castoria R, De Curtis F, Lima G, Caputo L, Pacifico S and De Cicco V (2001) Aureobasidium pullulans (LS-30), an antagonist of postharvest pathogens of fruits: Study on its modes of action. Postharvest Biological Technology 22:7-17.

10. Chan Z, Qin G, Xu X, Li B, Tian S (2007) Proteome approach to characterize proteins induced by antagonist yeast and salicylic acid in peach fruit. Journal of Proteome Research 6:1677-1688.

11. Droby S, Cohen L, Daus A, Weiss B, Horev B, Chalutz E, Shachnai A (1998) Commercial testing of Aspire: a yeast preparation for the biological control of postharvest decay of citrus. Biological Control 12:97-101.

12. Ebrahimi L, Aminian H, Etebarian HR, Sahebani N (2012a) Control of apple blue mould disease with Torulaspora delbrueckii in combination with Silicon. Archives of Phytopathology and Plant Protection 45:2057-2065.

13. Ebrahimi L, Etebarian HR, Aminian H, Sahebani N (2012b) Enhancement of biocontrol activity of Torulaspora delbrueckii with methyl jasmonate against apple blue mould disease. Archives of Phytopathology and Plant Protection 45:2355-2363.

14. Ebrahimi L, Etebarian HR, Aminian H and Sahebani N (2013a) Biological control of apple blue mold disease with Metschnikowia pulcherrima alone and in combination with silicon and its mechanisms of antagonism. Iranian Journal of Plant Pathology 49:39-40. (In Persian with English Abstract).

15. Ebrahimi L, Etebarian HR, Aminian H, Sahebani N (2013b) Effect of Metschnikowia pulcherrima and methyl jasmonate on apple blue mold disease and the possible mechanisms involved. Phytoparasitica 41:515-519.

16. El-Ghaouth A, Wilson CL, Wisniewski M (1998) Ultrastructural and cytochemical aspects of the biological control of Botrytis cinerea by Candida saitoana in apple fruit. Phytopathology 88:282-291.

17. El-Ghaouth A, Wilson CL, Wisniewski ME (2004) Biologically based alternatives to synthetic fungicides for the postharvest diseases of fruit and vegetables. pp.511-535. In: SA Naqvi (ed.), Diseases of Fruit and Vegetables, Dordrecht, the Netherlands: Kluwer Academic Publishers.

18. Etebarian HR, Farhangian-Kashani S, Ebrahimi L (2013) Combination of silicon and hot water to control of postharvest blue mould caused by Penicillium expansum in apple. International Journal of Agriculture 3:72.

19. Fan Q, Tian S (2001) Postharvest biological control of grey mold and blue mold on apple by Cryptococcus albidus (Saito) Skinner. Postharvest Biology and Technology 21:341-350.

20. Filonow AB, Vishniac HS, Anderson JA, Janisiewicz WJ (1996) Biological control of Botrytis cinerea apple by yeasts from various habitats and their putative mechanisms of antagonism. Biological Control 7:212-220.

21. Gholamnejad J, Etebarian HR, Sahebani N (2010) Biological control of apple blue mold with Candida membranifaciens and Rhodotorula mucilaginosa. African Journal of Food Science 4:1-7. 
22. Gholamnejad J, Etebarian HR, Roustaee A, Sahebani NA (2009) Biological control of apples blue mold by isolates of Saccharomyces cerevisiae. Journal of Plant Protection Research 49:270-275.

23. González-Estrada R, Blancas-Benítez F, Montaño-Leyva B, Moreno-Hernández C, Romero-Islas LDC, Romero-Islas J, Gutierrez-Martinez P (2018) A review study on the postharvest decay control of fruit by Trichoderma. Trichoderma-The Most Widely Used Fungicide 63.

24. Iavicoli A, Boutet E, Buchala A, Métraux JP (2003) Induced systemic resistance in Arabidopsis thaliana in response to root inoculation with Pseudomonas fluorescens CHA0. Molecular Plant-Microbe Interaction 16:851-858.

25. Janisiewicz WJ, Korsten L (2002) Biological control of postharvest diseases of fruits. Annual Review of Phytopathology 40:411-441.

26. Janisiewicz WJ, Roitman J (1988) Biological control of blue mold and gray mold on apple and pear with Pseudomonas cepacia. Phytopathology 78:1697-1700.

27. Kampp J (1990) Biological control of gray mold. Biologisk control of graskimmel. Pp. 90-5-6. The Institute of Biotechnology, Kolding, Denmark.

28. Kheireddine A, Essghaier B, Hedi A, Dhieb C, Zouaoui NS (2018) New epiphytic yeasts able to reduce grey mold disease on apples. Plant Protection Science 54:248-257.

29. Li BQ, Peng HM, Tian SP (2016) Attachment capability of antagonistic yeast Rhodotorula glutinis to Botrytis cinerea contributes to biocontrol efficacy. Frontiers in Microbiology 7:601.

30. Li RP, Zhang HY, Liu WM, Zheng XD (2011) Biocontrol of postharvest gray and blue mold decay of apples with Rhodotorula mucilaginosa and possible mechanisms of action. International Journal of Food Microbiology 146:151-156

31. Liu B, Qiao H, Huang L, Buchenauer H, Han Q, Kang Z, Gong Y (2009) Biological control of take-all in wheat by endophytic Bacillus subtilis E1R-j and potential mode of action. Biological Control 49:277-285.

32. McLaughlin RJ, Wilson CL, Chalutz E, Kurtzman CP, Fett WF, Osman SF (1990) Characterization and reclassification of yeasts used for biological control of postharvest diseases of fruits and vegetables. Applied and Environmental Microbiology 56:3583-3586.

33. McLaughlin RJ,Wilson CL, Droby S, Ben-Arie R, Chalutz E (1992) Biological control of postharvest diseases grape, peach and apple with the yeasts, Kloeckera apiculata and Candida guilliermondi. Plant Disease 76:470-473.

34. Mercier J, Wilson CL (1994) Colonization of apple wounds by naturally occurring microflora and introduced Candida oleophila and their effect on infection by Botrytis cinerea during storage. Biological Control 4:138-144.

35. Mercier J, Wilson CL (1995) Effect of wound moisture on the biocontrol by Candida oleophila of gray mold (Botrytis cinerea) of apple. Postharvest Biological Technology 6:9-15. 
36. Ongena M, Jacques P, Toure Y, Destain J, Jabrane A, Thonart P (2005) Involvement of fengycin-type lipopeptides in the multifaceted biocontrol potential of Bacillus subtilis. Applied and Environmental Microbiology 69:29-38.

37. Palou L, Ali A, Fallik E, Romanazzi G (2016) GRAS, plant-and animal-derived compounds as alternatives to conventional fungicides for the control of postharvest diseases of fresh horticultural produce. Postharvest Biology and Technology 122:4152 .

38. Parveen S, Wani AH, Bhat MY, Koka JA (2016) Biological control of postharvest fungal rots of rosaceous fruits using microbial antagonists and plant extracts-a review. Czech Mycology, 68.

39. Pelliccia C, Antonielli L, Corte L, Bagnetti A, Fatichenti F, Cardinali G (2011) Preliminary prospection of the yeast biodiversity on apple and pear surfaces from Northern Italy orchards. Annals of Microbiology 61:965-972.

40. Ramezani A, Mahdian S (2016) Biological Control of Post-Harvest Citrus Diseases. Plant Pathology Science 5:14-25.

41. Reeh KW (2012) Commercial bumble bees as vectors of the microbial antagonist Clonostachys osea for management of Botrytis blight in wild blueberry (Vaccinium angustifolium) (PhD diss.). 99p.

42. Rosenberger DA (1990) Blue Mold. Pp.54-55. In: AL, Jones HS, Aldwinckle (eds.). Compendium of Apple and Pear Diseases. St. Paul, American Phytopathological Society Press.

43. Ruiz-Moyano S, Martin A, Villalobos MC, Calle A, Serradilla MJ, Cordoba MG, Hernandez A (2016) Yeasts isolated from figs (Faicus carica L.) as biocontrol agents of postharvest fruit diseases. Food Microbiology 57:45-53.

44. Sharma R, Singh D, Singh R (2009) Biological control of postharvest diseases of fruits and vegetables by microbial antagonists: Biologyical Control 50:205-221.

45. Snowdon AL (1990) Pome fruits. Pp.170-218. In: AL Snowdon (ed.). A colour Atlas of Post-Harvest Diseases and Disorders of Fruits and Vegetables, General Introduction and Fruits. London.

46. Spadaro D, Vola R, Piano S, Gullino ML (2002) Mechanisms of action and efficacy of four isolates of the yeast Metschnikowia pulcherrima active against postharvest pathogens on apples. Postharvest Biology and Technology 24:123-134.

47. Talibi I, Boubaker H, Boudyach EH, Ait Ben Aoumar A (2014) Alternative methods for the control of postharvest citrus diseases. Journal of Applied Microbiology 117:1-17.

48. Vero S, Garmendia G, González MB, Bentancur O, Wisniewski M (2013) Evaluation of yeasts obtained from Antarctic soil samples as biocontrol agents for the management of postharvest diseases of apple (Malus domestica). FEMS Yeast Research 13:189-199.

49. Wang Y, Xu Z, Zhu P, Liu Y, Zhang Z, Mastuda Y, Toyoda H, Xu L (2010) Postharvest biological control of melon pathogens using Bacillus subtilis EXWB1. Journal of Plant Pathology 92:645-652 
50. Wenneker M, Thomma BP (2020) Latent postharvest pathogens of pome fruit and their management: from single measures to a systems intervention approach. European Journal of Plant Pathology 156:663-681.

51. Yu T, Zhang H, Li X and Zheng X (2008) Biocontrol of Botrytis cinerea in apple fruit by Cryptococcus laurentii and indole-3-acetic acid. Biological Control 46:171-177.

52. Zhang H, Wang L, Ma L, Dong Y, Jiang S, Xu B, Zheng X (2009) Biocontrol of major postharvest pathogens on apple using Rhodotorula glutinis and its effects on postharvest quality parameters. Biological Control 48:79-83.

53. Zhou T, Chu CL, Liu WT, Schaneider KE (2001) Postharvest control of blue mold and gray mold on apples using isolates of Pseudomonas syringae. Canadian Journal of Plant Pathology 92:645-652. 